\title{
Angiomyolipoma with Epithelial Cysts Masquerading as a Cystic Renal Cell Carcinoma
}

\author{
Andrew Wood Fiona Young Marie O'Donnell \\ Department of Pathology, Western General Hospital, Edinburgh, UK
}

\section{Key Words \\ Angiomyolipoma $\cdot$ Epithelial cysts $\cdot$ Renal cell carcinoma}

\begin{abstract}
Angiomyolipoma with epithelial cysts (AMLEC) is a very uncommon renal tumor. AMLEC has a characteristic histological appearance and immunohistochemical staining pattern, knowledge of which should preclude misdiagnosis by pathologists. We present a rare case of an AMLEC which was suspected to be a cystic renal cell carcinoma radiologically. We describe the characteristic immunological staining pattern and ultrastructural features of this lesion and discuss the potential differential diagnoses.
\end{abstract}

Copyright $\odot 2015$ S. Karger AG, Basel

\section{Case Report}

A 33-year-old obese female presented with a history of intermenstrual bleeding of several months duration. She was not taking any medications and specifically was not on any hormonal therapy. A pelvic ultrasound examination was carried out to exclude endometrial pathology. This identified a 5-6 cm mixed echogenicity lesion in the lower pole of right kidney. A subsequent CT urogram confirmed the presence of a 5-6 cm mixed cystic and solid mass in lower pole of right kidney (fig. 1a, 1b). The appearances were thought to be consistent with a renal cell carcinoma. She proceeded to right laparoscopic nephrectomy. Her post-operative period was complicated by a port site infection which was successfully treated with antibiotics. Subsequently the patient was assessed by the Genetics service for consideration of testing for tuberous sclerosis complex (TSC), but as she had no other features or family history of TSC, it was decided not to pursue genetic testing. At 9 months post-operation she has had no further complications.

\section{KARGER}

Fax +4161306 1234

E-Mail karger@karger.ch

www.karger.com
(C) 2015 S. Karger AG, Basel

1015-9770/15/0091-0209\$38.00/0

Accessible online at:

www.karger.com/cur
The surgical specimen consisted of a right lower pole tumor measuring $50 \times 30 \mathrm{~mm}$, the lesion was an exophytic, cream coloured, mixed cystic and solid mass located peripherally, protruding into but not invading extra-renal fat (fig. 1c).

Microscopically, the lesion showed cysts lined by hobnail apocrine cells. Immediately beneath the cysts, there were plump spindle cells and deep to that solid areas composed of monomorphic spindle cells. Thick walled blood vessels and sparse fat were also identified within the solid areas. There was no evidence of mitotic activity, necrosis or nuclear pleomorphism (fig. 1d, 2a).

Staining with antibodies to CK7 and panCK showed positive staining within the cyst epithelial lining cells. Staining with antibodies to smooth muscle actin and desmin was positive in the stroma away from the cyst walls and staining with antibodies to MelanA, HMB45, CD10, estrogen receptor and progesterone receptor was positive in the stroma immediately beneath the cysts (fig. 2b, 2c). There was no staining with antibodies to WT1, calretinin. Antibodies to CD34 outlined blood vessels only.

Electron microscopy reveals that the cystic areas were lined by large plump epithelioid cells with round nuclei and prominent nucleoli. These cells lay on a basement membrane in an overlapping cobblestone manner (fig 2d). Outwith the cystic areas the neoplasm contained spindled and epithelioid cells resembling those described in classical angiomyolipoma [1].

\section{Discussion}

Angiomyolipomas are benign clonal neoplasms containing thick walled blood vessels, smooth muscle stroma and adipose tissue. They are part of the perivascular epithelioid cell tumor familyand may be associated with TSC. Angiomyolipomas demonstrate coexpression of melanocytic markers and smooth muscle markers but are usually negative for cytokeratins. Several rare morphological variants including epithelioid, oncocytoma-like, 


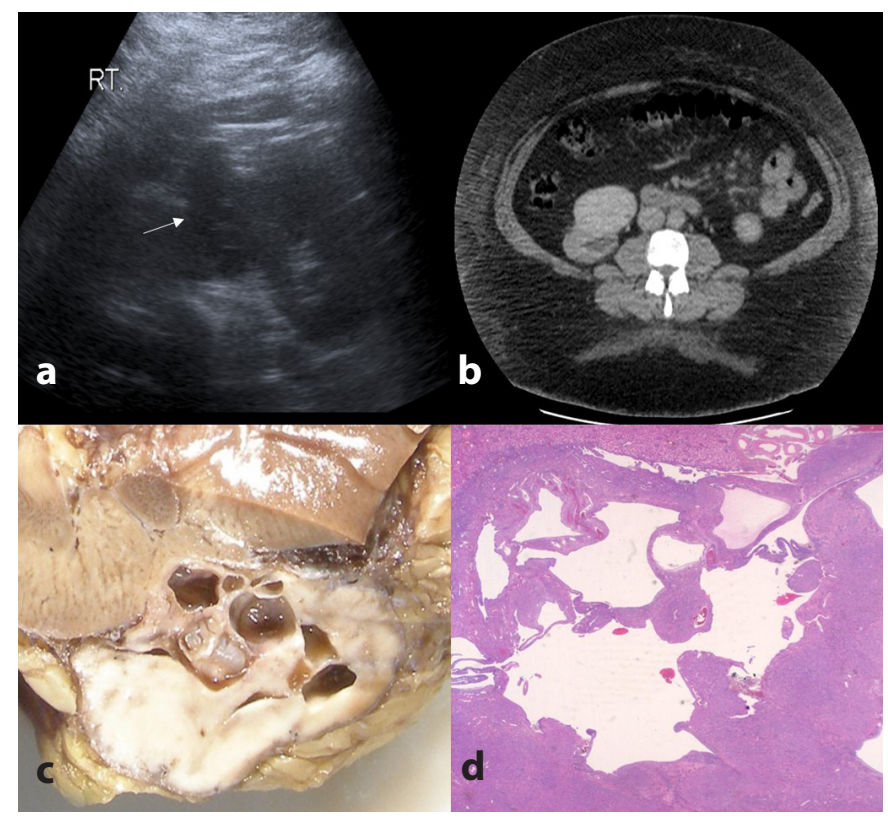

Fig. 1. a An abdominal ultrasound revealed a cystic lesion of the right kidney, confirmed on a subsequent CT scan. b The surgical specimen consisted of a pale solid and cystic exophytic lower pole tumor $\mathbf{c}$ and $\mathbf{d}$.

leiomyoma-like and liposarcoma-like have been reported and one rare variant is AMLEC [2]. AMLEC was first described by 2 groups in $2006[3,4]$ and a total of at least 26 cases have been reported to date [5-13] including one case classified as a PEComatous variant of mixed epithelial and stromal tumor [14]. As in this current case AMLEC have a characteristic appearance consisting of epithelial lined cysts, surrounded by a 'cambium-like' layer of Müllerian like stroma with variable chronic inflammation and a more solid central component with angiomyolipoma like stroma, thickened blood vessels and sparse fat $[3,4]$. Immunohistochemical studies show the stromal components label with antibodies to HMB45, Melan-A, CD10, estrogen receptor and progesterone receptor most intensely in the cellular subepithelial stroma, conversely smooth muscle actin and desmin demonstrated greatest intensity in the central muscle-predominant angiomyolipoma areas away from the epithelial cysts. The epithelial cysts are positive with antibodies to cytokeratins, a unique feature. There is no evidence that AMLEC is a specific lesion seen only in TSC and most cases described appear to have been sporadic in nature. The most important concern with AMLEC is that it is a lesion known to mimic renal cell carcinoma [15].

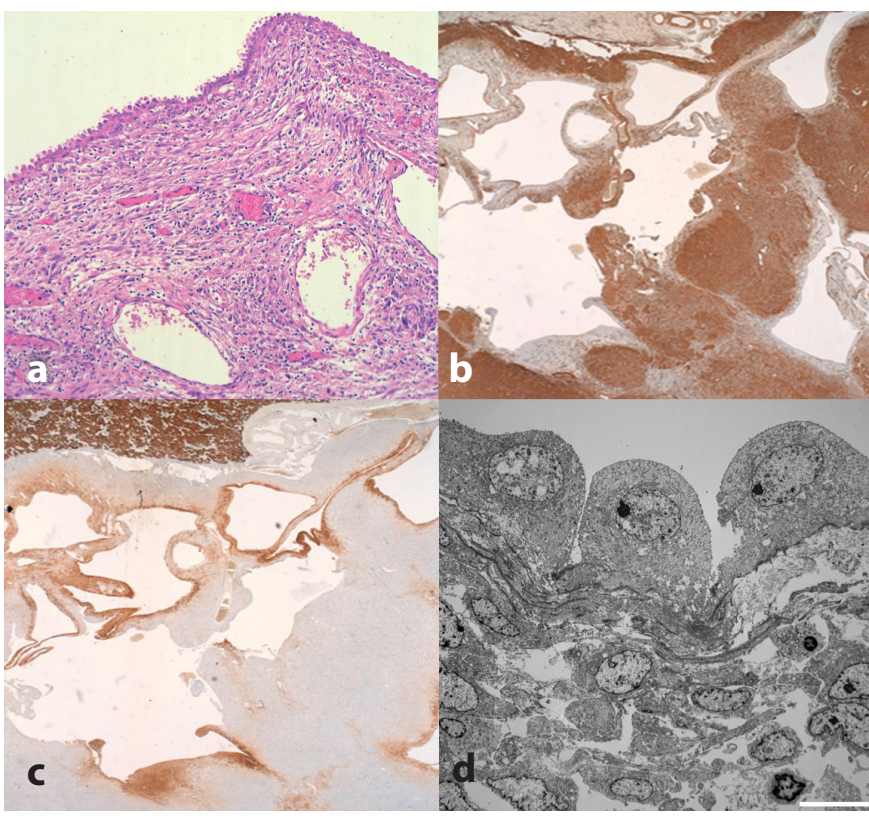

Fig. 2. a Shows the cystic component lined by epithelioid cells with 'apical snouts'. b Antibodies to smooth muscle actin, desmin stain the central muscle-predominant angiomyolipoma areas away from the epithelial cysts. c Antibodies to HMB45, Melan-A, CD10, ER and PR stain most intensely in the cellular subepithelial stroma (CD10 staining as exemplar). d Shows large epithelioid cyst lining cells with large nuclei and prominent nucleoli. These cells lie on a basement membrane in an overlapping manner.

The differential diagnosis of AMLEC includes cystic nephroma or mixed epithelial and stromal tumors [3], unlike AMLEC these lesions occur at the hilum of the kidney, contain ovarian like stroma and do not stain with melanocytic markers.

Tubulocystic renal cell carcinoma has a characteristic histological appearance and will not demonstrate the immunohistochemical profile seen here, cysts can occasionally occur in renal synovial sarcoma but the immunohistochemical appearances and translocations of this rare lesion are specific and lacking in AMLEC.

We describe here an AMLEC mimicking a cystic renal cell carcinoma on radiology. We provide a comprehensive morphological and immunohistological description of this rare lesion with the first ultrastructural description of the cyst lining cells. We are of the opinion that this rare entity should be kept in mind when considering the differential diagnosis of cystic renal masses. 


\section{References}

1 Barnard M, Lajoie G: Angiomyolipoma: immunohistochemical and ultrastructural study of 14 cases. Ultrastruct Pathol 2001;25:2129.

2 Gill S, Weber-Shrikant E, Chen F: A review of angiomyolipoma and its morphological variants. North Am J Med Sci 2011;4:84-88.

3 Davis CJ, Barton JH, Sesterhenn IA: Cystic angiomyolipoma of the kidney: a clinicopathologic description of 11 cases. Mod Pathol 2006;19:669-674.

4 Fine SW, Reuter VE, Epstein JI, Argani P: Angiomyolipoma with epithelial cysts (AMLEC): a distinct cystic variant of angiomyolipoma. Am J Surg Patho 2006;30:593-599.

5 Armah HB, Yin H, Rao UN, Parwani AV: Angiomyolipoma with epithelial cysts (AMLEC): a rare but distinct variant of angiomyolipoma. Diagn Pathol 2007;2:11.

6 Mikami S, Oya M, Mukai M: Angiomyolipoma with epithelial cysts of the kidney in a man. Pathol Int 2008;58:664-667.
7 Fernández CL, Martín EF, Ugarteburu RG, Canel BC, Torres GC, Toraño MA: Angiomiolipoma renal con quistes epiteliales (AMLEC): A propósito de un caso. Rev Esp Patol 2009;42:129-132.

8 Rosenkrantz AB, Hecht EM, Taneja SS, Melamed J: Angiomyolipoma with epithelial cysts: mimic of renal cell carcinoma. Clin Imaging 2010;34:65-68.

9 Karafin M, Parwani AV, Netto GJ, Illei PB, Epstein JI, Ladanyi M, Argani P: Diffuse expression of PAX2 and PAX8 in the cystic epithelium of mixed epithelial stromal tumor, angiomyolipoma with epithelial cysts, and primary renal synovial sarcoma: evidence supporting renal tubular differentiation. Am J Surg Pathol 2011;35:1264-1273.

10 Filho JD, Meneses De Amorim D, Sweet GM, Rodrigues De Freitas LA, Athanazio PR, Athanazio DA: Renal epithelioid angiomyolipoma with epithelial cysts: demonstration of Melan A and HMB45 positivity in the cystic epithelial lining. Ann Diagn Pathol 2012;16:397-401.
11 Park HG, Kim HJ, Jeong YB: Cystic angiomyolipoma mimicking cystic renal cell carcinoma on computed tomography image. Urology 2015;85:e43-e44.

12 Acar T, Harman M, Sen S, Kumbaracı BS, Elmas N: Angiomyolipoma with epithelial cyst (AMLEC): a rare variant of fat poor angiomyolipoma mimicking malignant cystic mass on MR imaging. Diagn Interv Imaging 2015;96:1195-1198

13 Gorin MA, Rowe SP, Allaf ME, Argani P: Urological Notes Angiomyolipoma with epithelial cysts : add one to the differential of cystic renal lesions. Int J Urol 2015;22:10811082.

14 Mai KT, Elkeilani A, Veinot JP: Mixed epithelial and stromal tumour (MEST) of the kidney: report of 14 cases with male and PEComatous variants and proposed histopathogenesis. Pathology 2007;39:235-240.

15 Schieda N, Kielar AZ, Al Dandan O, McInnes MD, Flood TA: Ten uncommon and unusual variants of renal angiomyolipoma (AML): radiologic-pathologic correlation. Clin Radiol 2015;70:206-220. 